\title{
Women Investors' Preferences: Case of Jordan
}

\author{
Asma’a AL-Amarneh \\ Correspondence: Asma'a AL-Amarneh, Associate professor, Financial and Banking Science Department, Applied \\ Science Private University, Jordan, P.O Box 166, Postal Code 11931-Amman-Jordan. E-mail: a_alamarneh@asu.edu.jo
}

Received: February 2, 2016

Accepted: February 14, 2016

Online Published: March 5, 2016

doi:10.5539/ibr.v9n4p73

URL: http://dx.doi.org/10.5539/ibr.v9n4p73

\begin{abstract}
Women participation in the Jordanian Security market were recognized to be limited compared to men participation. During the last five years, their holdings increased from (469) million to (524) million shares, with $12 \%$ growth rate. This paper is the first empirical study that investigates the factor affecting women security selections by focusing on an emerging country, Jordan. The results show that Jordanian women investors prefer to invest in mature companies with large cap that are using their earning to pay dividend. They also, a value investors seeking undervalued shares for solid companies to invest in, then sell them high when the market derives the prices back up. In general, Jordanian women are risk-averse investors focus on perceived safety and require high rate of return for acquiring a higher level of risk. The findings of this paper could be the first step toward improving the participation of Jordanian women in investment activity and increasing the liquidity and efficiency of Amman stock Exchange.
\end{abstract}

Keywords: investment preferences, individual investor, women, Amman Stock exchange, Jordan

\section{Introduction}

\subsection{Problem Statement}

The Jordanian population characterized by rapid growth (2.2 percent annual growth rate) and young (59.5 percent of population between 15-64 years). Women represent 48.5 percent of this population; but their participation in economic activity is considered weak since 13.2 percent of economic activity is supplied by women. According to statistics; 95.8 percent of women in Jordan are paid employee; mainly work in education, health and communication. While; in the financial activity, only 49.5 percent of persons receiving loans were women with 30.8 percent of the total value of loans and 43.2 percent of owners of securities (shares) were women with total value of 6.36 percent of total value. These figures indicate that women are limited players in the securities market and surely have their own investment decisions and portfolio selection strategies.

With all of these in mind, this study aims to: 1) sheds light on women participation on the equity market. 2) Investigate the firm specific and stock specific factors which influence women preferences as an investor and their investment decisions.

\subsection{Problem Importance}

The result of this paper is important to increase investment activity of Jordanian women which will increase the market liquidity and improve investment environment and market efficiency of Amman Stock Exchange (ASE).

The share holding of women is taken in percentage form to control for the firm size. The relationship is observed by correlation and regression coefficients.

\subsection{Literature Review}

Individual female investors exhibit trading behaviors different from those of male investors. These behaviors have been observed, analyzed and documented in a growing body of finance literature, this study contribute to behavioral finance literature by adding new information and statistics about women participation in Jordanian stock market and their preferences.

Empirical studies of the behavior of individual investors first appeared in the 1970s. The Wharton survey examines how demographic variables influence the investment selection and portfolio composition process.

Lewellen, lease and Schlarbaum (1977) determine that age, sex, income and education affect investor preferences for capital gain, dividend yield and overall return.

Stinerock, stern and Solomon (1991) found that women had lower risk preference and a higher degree of anxiety in 
financial decisions than men.

Powell and Ansic (1997) found that gender is an important factor that influences investment decision making with women being more risk averse and employing different decision making strategies when making financial decisions compared to men.

Estes and Hosseini (1988) also demonstrated that gender was the most important explanatory factor affecting confidence in investment decisions. Female were less confident than males after controlling for the effect of other variable such as age, education, knowledge and experience.

Furthermore, Barber and Odean (2001) document that in area of finance, men are more overconfident than women and men trade more excessively than women. After analyzing the trading records during 1991-1997 they found that men trade 45 percent more than women. Trading reduces men's returns by 2.65 percentage points a year as opposed to 1.72 percentage points for women. Also, women tend to hold less risky positions than men within their common stock portfolios.

Heminway (2009) found that women and men exhibit a different investment behavior and achieve different investment outcomes and resulting female investment profile is closer to existing conceptions of the reasonable investor than resulting male investment profile. The study significant key findings were women are more likely to seek investment advice than men also they research and understand their investment more than men. The results assured that women are more risk averse than men; this risk aversion appear in portfolio asset allocation and loss-aversion behaviors.

Al-Ajmi (2011) study the risk tolerance for the individual investor in Bahrain, he found that men have high propensity towards risk tolerance than women and he recommended that men and women should not treated as a homogenous group because of these differences.

Bashir et.al. (2013) study the relationship between demographic (age, gender, education and income) and investment preferences consisting of stock investment and gambling decisions of salaried individuals of finance teachers and bankers. Their findings indicate that females are more risk averse than males but young and educated people are attractive more towards new risky investments.

Bayyurt et. al. (2013) explored the differences between women and men in their investment preferences by analyzing their attitude towards six investment tools, namely, gold, foreign currency, fund, real estates, common stocks and time deposits. The results revealed that while men investors prefer common stocks and real estate to invest, women investors are more risk averse and invest in fund, time deposit and old. There are no significant differences between men and women in foreign currency investment.

\subsection{Hypotheses Development}

According to the previous literature; women looking for low risk investment and get low return. But none of the paper has investigated the women preferences according to firm or stock specific characteristics. In this paper, we are interested in investigating the main characteristics of firms that women in Jordan preferred to invest their money in and the main characteristics of stocks they prefer to hold.

The following hypotheses will be tested:

Hypothesis 1: corporate performance has a positive effect on women holdings

Hypothesis 2: stock performance has a positive effect on women holdings

\section{Method}

\subsection{Sample Selection and Data Collection}

Our sample consists of all firms listed in Amman Stock Exchange and has all the required data during the period of the study.

Table 1. Distribution of women holdings during 2010-2014

\begin{tabular}{ll}
\hline Year & Number of companies with woman's share holdings \\
\hline 2010 & 263 \\
2011 & 265 \\
2012 & 265 \\
2013 & 261 \\
2014 & 260 \\
\hline
\end{tabular}

Source: Security Depository Center- Jordan

By the end of 2014 there were (277) companies listed in ASE and distributed among three main industry sectors. Women holdings were distributed among (263) listed companies by the end of 2010 and increased by the end of 2011 
and 2012 to (265) listed companies. Women start to close their positions by the end of 2013 and 2014 and keep holding of shares in (260) listed companies only.

To construct a balanced panel data, we select all common companies during the study period and end up with (192) companies for each year, which means there are (960) observations for each variable included in the study model. Our sample classified according to the type of industry as follows:

Table 2. Classification of companies according to industry type during 2010-2014

\begin{tabular}{ccc}
\hline Industry type & Number of companies in our sample & Number of observations \\
\hline Financial sector & 95 & 475 \\
Service Sector & 47 & 235 \\
Industrial Sector & 50 & 250 \\
Total & $\mathbf{1 9 2}$ & $\mathbf{9 6 0}$ \\
\hline
\end{tabular}

Source: ASE annual report -2014.

\subsection{Variables and Model}

The focal point in this study is to test the main firm specific characteristics that attract women investments. The firm specific characteristics (corporate financial performance and stock performance) are measured and their relationship to women holdings was analyzed.

The dependent variable: women holdings: measured by the percentage of shares outstanding held by women.

Independent variables: corporate financial performance and stock performance.

Corporate financial performance: is measured by using the following financial indicators: return on equity (ROE), financial leverage, dividend yield, risk level and we control for the firm size and type of industry using the industry dummy variable.

Stock performance: is measured by the following indicators: price to book ratio $(\mathrm{P} / \mathrm{B})$, trading volume, market capitalization, share turnover, systematic risk and the market return.

In particular, our study is attending to test the following models:

$$
\begin{gathered}
\text { Women Holdings } \mathrm{i}, \mathrm{t}=\alpha 1+\text { Corporate finacial perfromance } \mathrm{i}, \mathrm{t}-1+\mathrm{Ci}, \mathrm{t}-1+\varepsilon \mathrm{i}, \mathrm{t} \\
\text { Women Holdings } \mathrm{i}, \mathrm{t}=\alpha 1+\text { Stock perfromance } \mathrm{i}, \mathrm{t}-1+\mathrm{Ci}, \mathrm{t}-1+\varepsilon \mathrm{i}, \mathrm{t}
\end{gathered}
$$

Where $\alpha$ represent the regression coefficient, $\varepsilon$ the error term and $\mathrm{C}_{\mathrm{i}, \mathrm{t}-\mathrm{1}}$ represent the control variable matrix.

\section{Results}

\subsection{Statistics and Data Analysis}

The data analyzed in this study come from security Depository Center (SDC) and Amman Stock Exchange (ASE) during the period from 2010 to 2014. To achieve the goal of this paper two types of data were collected, the data related to women ownership in different listed companies were collected from the SDC records, while financial figures related to these firms were collected from the ASE publications. Table 3 presents the average performance of ASE during the study period. The figures represent a decrease in performance as a result of world financial crisis and political circumstances in the region.

Table 3. ASE performance during 2010-2014

\begin{tabular}{llllll}
\hline year & 2010 & 2011 & 2012 & 2013 & 2014 \\
\hline Market Capitalization(million JD) & $21,858.2$ & $19,272.8$ & $19,141.5$ & $18,233.5$ & $18,082.6$ \\
Trading Volume( million JD) & $6,690.0$ & $2,850.3$ & $1,978.8$ & $3,027.3$ & $2,263.4$ \\
Shares Turnover & 102.2 & 58.2 & 33.9 & 38.0 & 32.8 \\
Price weighted market index & 5318.0 & 4648.4 & 4593.9 & 4336.7 & 4237.6 \\
P/E & 26.3 & 22.6 & 15.6 & 14.7 & 15.3 \\
P/B & 1.7 & 1.5 & 1.5 & 1.3 & 1.3 \\
Div. Yield & 2.7 & 3.3 & 4.6 & 4.6 & 4.2 \\
Market Cap. To GDP \% & 122.7 & 102.7 & 93.5 & 83.0 & 75.8 \\
\hline
\end{tabular}

Source: ASE annual report -2014.

Table 4 presents the classification of ownership according to gender during the study period. Figures in this table represent the number of shareholder, number of securities held by men and women and the total market value of these securities. 
Table 4. Ownership analysis according to investor category (2010-2014)

\begin{tabular}{lllll}
\hline year & Gender & Shareholder & Securities & Total Value \\
\hline 2010 & Male & 390,526 & $2,538,791,694$ & $4,531,449,904.08$ \\
& Female & 243,071 & $468,824,346$ & $1,312,766,709.08$ \\
2011 & Male & 389,100 & $2,639,044,056$ & $3,860,703,838.12$ \\
& Female & 246,136 & $496,009,709$ & $1,101,748,399.74$ \\
2012 & Male & 377,489 & $2,650,663,452$ & $3,743,446,111.72$ \\
& Female & 242,053 & $499,467,725$ & $1,040,656,781.74$ \\
2013 & Male & 374,393 & $2,716,025,273$ & $4,230,548,389.57$ \\
& Female & 243,150 & $510,169,355$ & $1,111,069,263.8$ \\
2014 & Male & 369,191 & $2,718,444,175$ & $4,387,691,117.50$ \\
& Female & 242,272 & $524,385,251$ & $1,154,492,981.15$ \\
\hline
\end{tabular}

Source: Security Depository Center- Jordan

The table shows that the number of securities held by women increased during the study period from approximately (469) million shares to (524) million shares, indicating that women interest in equity market increased by $12 \%$ during the last five years, but still far away from men figures (see figure 1).

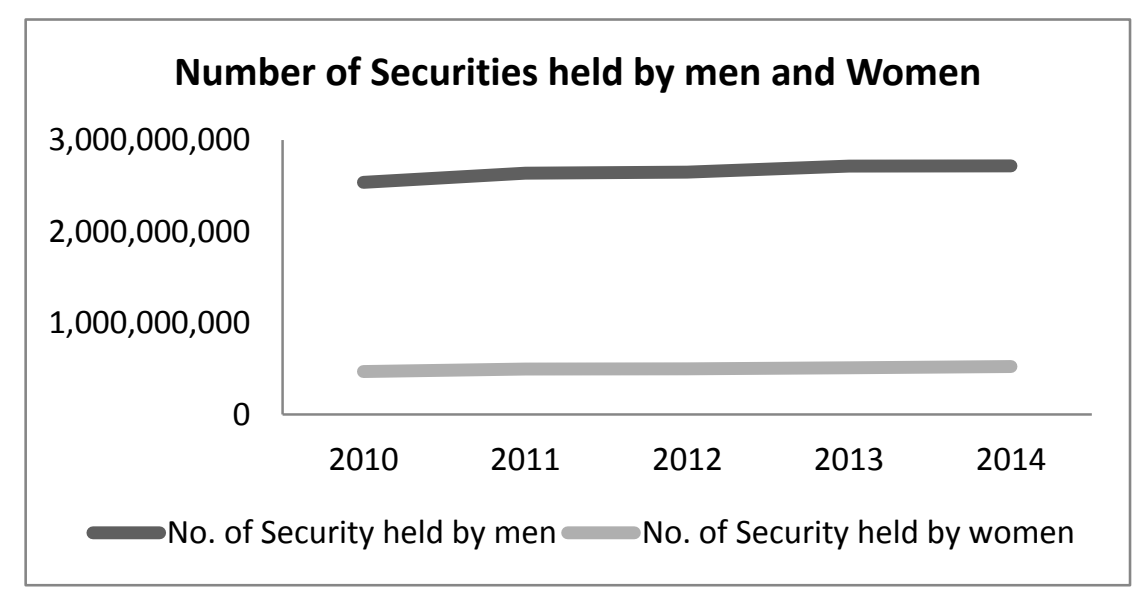

Figure 1. Number of securities held by Men and Women during 2010-2014

When classifying women holdings according to certain firm specific factors and share stock specific factors we found the following:

- According to Industry sector; women holdings in each industry type is classified as follows: on average Jordanian women hold about 7.96 percent of total securities in financial sector (banks, insurance companies, financial services and real estate companies), 9.40 percent of total securities in service sector (health care, education, transportation...) and 8.05 percent of total securities in industrial sector (chemical, pharmaceutical, mining and extraction, engineering and construction..)

- According to profitability; women hold about 9.2 percent of total securities with positive market return and 7.7 percent of total securities with negative market return. Also, women hold about 8.40 percent and 8.54 percent of companies with positive return on equity (ROE) and positive return on assets (ROA), respectively; indicating that Jordanian women look for profitable investment.

- According to financial leverage degree; women hold 6.0 percent in companies with low leverage degree (number of observations 682 of 960), 5.0 percent in medium leverage level and 4.0 percent in highly leveraged firms indicating that Jordanian women were risk averse.

- $\quad$ According to company size; women holdings concentrated in small companies (99.5 percent) with total assets less than 10 Billion JD and their holdings reach 8.30 percent of these companies, while they hold 12.80 percent of securities related to large companies.

- According to stock price; 97.7 percent of women holdings were in companies with stock price less than (10) JD and they hold about 8.46 percent of these companies, while their holdings in highly priced stock didn't exceed 3.20 percent.

- $\quad$ According to systematic risk of the stock (Beta); 67.5 percent of observations were positive $(+$ Beta) which means the stock return go with the market return in the same direction and women hold on average 8.1 percent of the securities in these companies, while their investments in a negative beta companies were near 8.6 percent. 
Table 5 shows that; on average Jordanian women present $32.9 \%$ of shareholders, with security holdings of 8.3 percent only as a percentage of total securities. The selected companies on average have a share price of (1.03) JD, with price volatility of (11\%), and market capitalization of ( 2 million) JD and average trading value per company was ( 8 million) JD, while the company size measured by total assets was ( 16.0 million) JD on average. The financial performance of the selected companies was bad during 2010 - 2014 since 361 (37.6 percent) of the ROE observations was negative also 34.38 percent of the ROA observations (The ROA figures were analyzed but not shown in the table) was negative, too; while the market return on average was -3.90 percent with 60.8 percent of the observation were negative indicating a bad performance of the selected companies' shares in the market. Mainly, about $31.0 \%$ of the capital of our sample comes from debt. Concerning the market value of our sample; the results show that stocks were undervalued (Tobin'Q ratio on average $=0.70$ ) with low systematic risk on average (Beta $=0.51$ ).

Table 5. Descriptive statistics.

\begin{tabular}{|c|c|c|c|c|c|c|c|c|c|c|c|c|c|c|c|}
\hline & & Price & Market & Beta & LN & $\mathrm{LN}$ & LN & TURNOVER & R DIVYIELD & РТOB & ROE & LEVERAGE & TOBINQ & HOLDERPER & SECPER \\
\hline Mean & 1.868706 & 0.197529 & 0.514490 & 0.502360 & 29.83134 & 15.60073 & 15.03033 & 366.73287 & 1.807525 & 1.141911 & -35.03905 & 36.39304 & 6.196567 & $7 \quad 0.329758$ & 0.083468 \\
\hline Median & 1.030000 & 0.110000 & -0.039227 & 70.248608 & 14.56000 & 15.89000 & 16.57410 & 16.39000 & 0.000000 & 0.890000 & 2.100000 & 31.08000 & 0.730931 & 10.330000 & 0.060000 \\
\hline Maximum & 43.63080 & 7.522271 & 374.6251 & 4.774935 & 3073.072 & 21.04716 & 23.97595 & 51947.040 & 17.95000 & 25.68000 & 816.5100 & 119.2518 & 161.5385 & 0.520000 & 0.68000 \\
\hline Minimum & 0.080000 & 0.000000 & -0.986740 & $0-1.971001$ & 10.000000 & 5.000000 & -2.210000 & 00.000000 & 0.000000 & -6.457749 & $9-34544.15$ & 0.020000 & 0.000000 & 0.100000 & 0.0000 \\
\hline Std. Dev. & 3.302415 & 0.367234 & 12.34793 & 1.028786 & 125.9487 & 2.122216 & 5.891805 & 5172.7876 & 2.986257 & 1.214790 & 1117.273 & 26.92495 & 14.79576 & 60.083530 & 0.093087 \\
\hline Observations & 960 & 960 & 960 & 960 & 960 & 960 & 960 & 960 & 960 & 960 & 960 & 960 & 960 & 960 & 960 \\
\hline
\end{tabular}

To test the first hypothesis we run the OLS regression (random effect) to find the effect of firm financial performance on women investments in any company. The results show that the most significant factors were ROE and Dividend Yield, they affect women holdings positively and significantly. Financial leverage and firm size have a negative insignificant effect on women holdings indicating that women don't like investment in high leveraged firms such as banks and insurance companies, and prefer to invest in small companies (size measured by total assets) whatever the sector was. Also, about 91.0 percent of changes in women holdings were explained by this group of firm specific factors with high confidence level.

Table 6. Regression Analysis Results (Random effect) to test the effect of company financial performance.

\begin{tabular}{ccccc}
\hline \multicolumn{1}{c}{ Variable } & Coefficient & Std. Error & t-Statistic & Prob. \\
\hline ROE(-1) & $2.44 \mathrm{E}-07$ & $7.49 \mathrm{E}-08$ & 3.256296 & 0.0012 \\
LEVERAGE(-1) & $-3.33 \mathrm{E}-05$ & $3.79 \mathrm{E}-05$ & -0.879270 & 0.3795 \\
DIVYIELD(-1) & 0.000334 & 0.000196 & 1.704146 & 0.0888 \\
LN(TA) & -0.000147 & 0.000125 & -1.173533 & 0.2409 \\
SECPER(-1) & 1.018650 & 0.052512 & 19.39833 & 0.0000 \\
$\quad$ C & 0.003964 & 0.005447 & 0.727620 & 0.4671 \\
R-squared: & 0.910018 & & & \\
Adjusted R-squared & 0.909426 & & & \\
F-statistic & 1537.221 & & & \\
Prob(F-statistic) & 0.000000 & & & \\
Durbin-Watson stat & 2.188035 & & & \\
\hline
\end{tabular}

We run the OLS regression (random effect) again to test the second hypothesis; the results show that stock market return was the most significant factor that affects positively the women holdings in ASE. In addition, the market capitalization has a significant positive effect on women holdings. Although company size measured by total assets has a negative insignificant effect, the market capitalization as a proxy of size has a positive and significant effect on women selections. In the other hand, price to book value ratio has a negative significant effect on women holdings indicating that Jordanian women are value investors who prefer stocks with low market to book value, which considered as undervalued stocks in other words; Jordanian women prefer value stocks that pay dividend most of the time. The sign for systematic risk (beta) coefficient was negative but not significant indicating to a certain limit that Jordanian women are pessimistic investors and risk averse; they choose an investment with small betas (low systematic risk). It is clear that Jordanian women were not interested in stock liquidity (stock turnover ratio) and stock trading value. 
Table 7. Regression Analysis Results (Random effect) to test the effect of stock performance.

\begin{tabular}{|c|c|c|c|c|}
\hline Variable & Coefficient & Std. Error & t-Statistic & Prob. \\
\hline LN(TRADING) & -0.000389 & 0.000363 & -1.071855 & 0.2841 \\
\hline LN(MARKETCAP) & $2.21 \mathrm{E}-05$ & $5.97 \mathrm{E}-06$ & 3.693048 & 0.0002 \\
\hline PTOB & -0.001282 & 0.000590 & -2.171397 & 0.0302 \\
\hline MARKETRETURN & 0.015758 & 0.002324 & 6.781312 & 0.0000 \\
\hline BETA & -0.000394 & 0.000475 & -0.828083 & 0.4079 \\
\hline $\operatorname{SECPER}(-1)$ & 1.012902 & 0.008592 & 117.8850 & 0.0000 \\
\hline $\mathrm{C}$ & 0.008462 & 0.005736 & 1.475294 & 0.1405 \\
\hline R-squared & 0.906097 & & & \\
\hline Adjusted R-squared & 0.905232 & & & \\
\hline S.E. of regression & 0.028034 & & & \\
\hline F-statistic & 1047.642 & & & \\
\hline Prob(F-statistic) & 0.000000 & & & \\
\hline Durbin-Watson stat & 2.107802 & & & \\
\hline
\end{tabular}

\section{Discussion}

Jordanian women are limited participant in the Jordanian Security market and their participation increased during the Last five years (2010-2014). This paper is the first one that investigates empirically the main factors affecting Jordanian women investments in Amman stock Exchange (ASE).The results show that Jordanian women prefer to invest in mature companies that are using their earning to pay dividend. In addition, women mostly invest in small sized companies with low level of financial leverage. When analyzing the risk preference for Jordanian women we found that they are risk averse investors focus on perceived safety and require high rate of return for acquiring a higher level of risk. Also, Jordanian women are founded to be a value investor; they seek to buy stock of a solid company that is undervalued for some reason, and then sell them at a higher price when the market drives the stock price back up.

The results of this paper could be the first step toward increasing the participation of Jordanian women in Amman Stock Exchange by investigating their preferences first then try to develop a program to help them to involve more in investment activity to increase the market liquidity and improve investment environment and market efficiency of ASE.

\section{Acknowledgments}

The author is grateful to the Applied Science Private University, Amman, Jordan for the full financial support granted to this research project (Grant No: DRGS-2014-2015-118)

\section{References}

Al-Ajami, J. (2011). Risk tolerance and individual investor in an emerging market. Journal of risk and Diversification.2: 102-112.

Bashir, T., Ahmed, H., Jahangir, S., Zaigham, S., Saeed, H., \& Shafi, S. (2013). Investment preferences and risk level: Behaviour of salaried individuals. IOSR Journal of Business and management, 10(1), 68-78. http://dx.doi.org/10.9790/487x-1016878

Bayyurt, N., Karisik, V., \& Coskun, A. (2013). Gender differences in investment preferences.European Journal of Economic and political studies, 6(1), 71-83.

Brad, M. B., \&Terrance, O. (2001). Boys will be boys: gender, overconfidence, and common stock investment. The quarterly Journal of Economics, 116(1), 261-292. http://dx.doi.org/10.1162/003355301556400

Estes, R., \& Hosseini, J. (1988). The gender gap on Wall Street: An empirical analysis of confidence in investment decision making. The Journal of Psychology: Interdisciplinary and applied, 122(6), 577-590. http://dx.doi.org/10.1080/00223980.1988.9915532

Heminway, J. M. (2009). Female investors and securities fraud: is the reasonable investor a woman? William and Mary Journal of women and the law, 15(2), 291-336.

Lewellen, W. G., Roland, C. L., \& Gary, G. S. (1977). Pattern of investment strategy and behavior among individual investors. Journal of business, 50(3), 296-333. http://dx.doi.org/10.1086/295947.

Powell, M., \& Ansic, D. (1997). Gender differences in Risk Behavior in Financial Decision-Making: An Experimental analysis. Journal of Economic Psychology, 18(6), 605-628. http://dx.doi.org/10.1016/S0167-4870(97)00026-3

\section{Copyrights}

Copyright for this article is retained by the author(s), with first publication rights granted to the journal.

This is an open-access article distributed under the terms and conditions of the Creative Commons Attribution license (http://creativecommons.org/licenses/by/3.0/). 